Article

\title{
Gold Nanoparticle-Based Colorimetric and Electrochemical Methods for Dipeptidyl Peptidase-IV Activity Assay and Inhibitor Screening
}

\author{
Ning Xia *, Xin Wang, Xiaojin Wang and Binbin Zhou \\ Henan Province of Key Laboratory of New Optoelectronic Functional Materials, \\ College of Chemistry and Chemical Engineering, Anyang Normal University, \\ Anyang 455000, Henan, China; wangx933@nenu.edu.cn (X.W.); xjwanghxx@sohu.com (X.W.); \\ xrc1202@gamil.com (B.Z.) \\ * Correspondence: xianing82414@csu.edu.cn; Tel.: +86-732-290-0040 \\ Academic Editor: Ilaria Fratoddi \\ Received: 3 September 2016; Accepted: 13 October 2016; Published: 21 October 2016
}

\begin{abstract}
We presented the colorimetric and electrochemical methods for determination of the dipeptidyl peptidase-IV (DPP-IV) activity and screening of its inhibitor using gold nanoparticle $(\mathrm{AuNP})$ as the probe. In the colorimetric assay, the substrate peptide with a sequence of Arg-Pro-Arg induced the aggregation and color change of AuNPs, whereas cleavage of the peptide by DPP-IV prevented the aggregation of AuNPs. Furthermore, the aggregation of AuNPs in the solution was easily initiated on a solid/liquid (electrode/electrolyte) surface, which induced a decrease in the electron-transfer resistance. However, once the peptide was clipped by DPP-IV, the assembly of AuNPs on electrode surface was prevented. Consequently, a higher electron-transfer resistance was observed. The colorimetric and electrochemical assays allowed for the determination of DPP-IV with the detection limits of $70 \mu \mathrm{U} / \mathrm{mL}$ and $0.55 \mu \mathrm{U} / \mathrm{mL}$, respectively. Meanwhile, the proposed methods were used to determine DPP-IV inhibitor with satisfactory results. Both the colorimetric and electrochemical methods are simple, rapid and sufficiently sensitive for DPP-IV activity assay and inhibitor screening. The results also demonstrated that the AuNP-based colorimetric assay could be converted into an enhanced surface tethered electrochemical assay with improving sensitivity. The simple detection principle may be extended to the design of other peptidases biosensors with easy manipulation procedures.
\end{abstract}

Keywords: dipeptidyl peptidase-IV; gold nanoparticles; colorimetric assay; electrochemical impedance spectroscopy; inhibitor screening

\section{Introduction}

Diabetes is a group of metabolic disorder diseases. Type 2 diabetes, accounting for $90 \%-95 \%$ of all the cases, is characterized by high blood sugar, insulin resistance, and relative lack of insulin [1]. Recently, new therapies for managing this disease are focusing on modulation of the incretins glucose-dependent insulinotropic polypeptide (GIP) and glucagon-like peptide-1 (GLP-1), two peptidic hormones with glucose-dependent insulin secretion promotion and $\beta$-cell-proliferative effect [2,3]. However, these hormones show a rather short half-life to dipeptidyl peptidase-IV (DPP-IV, EC 3.4.14.5) [4]. Optimistically, DPP-IV inhibitors can be used to increase the lifetime of incretins by reducing DPP-IV activity, and DPP-IV has been regarded as the prime drug target to treat and prevent type 2 diabetes [2]. Although many of the inhibitors, such as sitagliptin, vildagliptin, and saxagliptin, exhibited impressive intrinsic potencies by lowering the level of serum glucose, these drugs also lead to some undesired side effects, such as angioedema, pancreatitis, and infective disorders [5,6]. Therefore, novel DPP-IV inhibitors were desired for the management of type 2 diabetes [7,8]. The currently used methods for 
monitoring DPP-IV activity and screening of its inhibitor include spectrophotometry, fluorescence, high performance liquid chromatography (HPLC) and mass spectrometry [9-12]. These methods are feasible, but are high-cost and time-consuming and require the use of labeled substrates and sophisticated instrumentations. Thus, the development of simple, sensitive and cost-efficient methods for probing of DPP-IV activity and screening of its inhibitor are still desired.

In recent years, gold nanoparticles (AuNPs) have been used as the excellent scaffolds for the design of chem/bio-sensors due to their distinct physical and chemical properties [13-20]. For example, because of their high extinction coefficients and the unique size-dependent optical properties, AuNP-based colorimetric assays have been reported for detection of many types of analytes, including monitoring the enzyme activity [21-26] and measuring the concentration levels of nucleic acids [27-29], proteins [30,31], metal ions [32-34] and other small molecules [35-39]. As to the assay of protease activity with AuNPs as the probes, two strategies could be commonly used. In the first method, peptide substrate containing two binding tags can crosslink AuNPs before the enzymatic reaction, thus inducing their aggregation and color change [24]. The second method is based on the non-crosslinking AuNPs aggregation in which the peptide substrate either before or after the cleavage reaction could cause the loss of surface charges of AuNPs and destroy the stability of the negatively charged AuNPs $[25,26]$. Since DPP-IV is a peptidase responsible for the cleavage of X-Pro-peptide, where $\mathrm{X}$ represents an amino residue, the previously reported AuNP-based colorimetric protease assays pave us a new way for the detection of DPP-IV by rationally designing the sequence of DPP-IV substrate.

Herein, we found that the tripeptide (Arg-Pro-Arg) with two positively charged arginine residues could induce the aggregation and color change of AuNPs, whereas cleavage of the peptide into arginine and dipeptide (Pro-Arg) by DPP-IV prevented the aggregation of AuNPs (Scheme 1). This colorimetric methodology is simple because it does not require modification of analyte-binding molecules onto AuNPs. However, the colorimetric method showed poor sensitivity. Since gold electrode exhibits a superficial microenvironment similar to that of AuNPs [40], we suggested that modification of gold electrode with the peptide substrate allowed for the deposition of increasing amounts of AuNPs on the electrode surface through the tripeptide-induced assembly of AuNPs (Scheme 2), that is, the sensing electrode can capture AuNPs and free tripeptide in the solution through the peptide-AuNPs-tripeptide interaction. Then, surface-tethered peptide-AgNPs-tripeptide recruited more AuNPs as well as tripeptide, resulting in the formation of a network of AuNPs-tripeptide on the electrode surface. Thus, the aggregation of AuNPs in a solution would be facilely initiated on a solid/liquid (electrode/electrolyte) surface, yet cleavage of the peptide substrate either on electrode surface or in solution by DPP-IV prevented the assembly of AuNPs. Consequently, the liquid-phase colorimetric assay was converted into enhanced surface tethered electrochemical analysis for probing of DPP-IV activity.

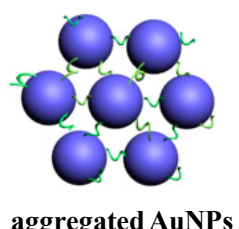

aggregated AuNPs

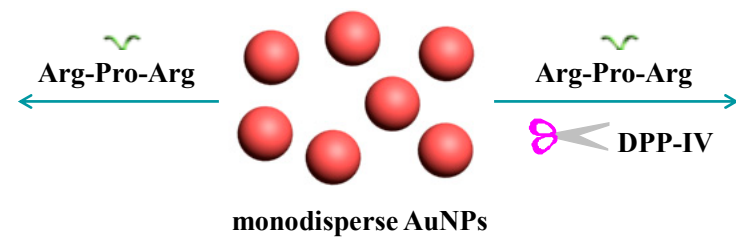

Scheme 1. Schematic illustration of the colorimetric assay of dipeptidyl peptidase-IV (DPP-IV) activity using gold nanoparticles (AuNPs) as the probes. 


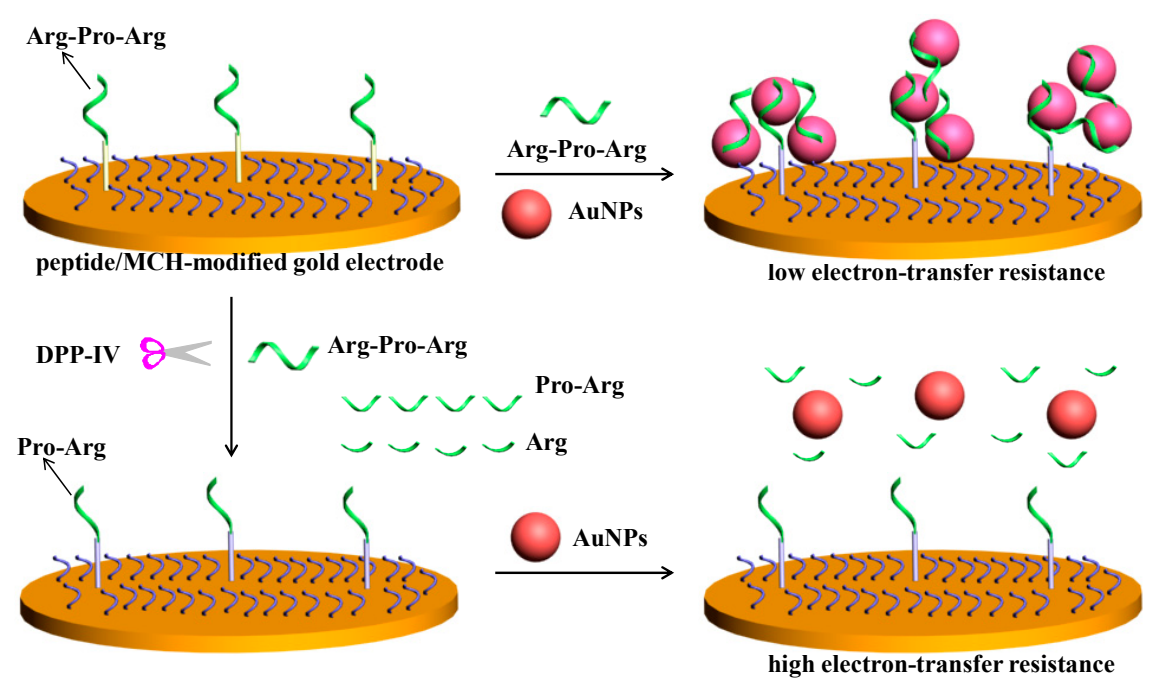

Scheme 2. Schematic illustration of the electrochemical method for DPP-IV activity assay.

\section{Results and Discussion}

\subsection{Feasibility for Colorimetric Assay of DPP-IV}

To prove that the tripeptide Arg-Pro-Arg could be clipped by DPP-IV, the mixture of tripeptide/Arg-Pro-Arg was incubated for $1 \mathrm{~h}$ and then characterized by mass spectrometry in a positive-ion mode. As a result, two new dominant mass peaks at 175.1194 Da and 272.1741 Da were observed, corresponding to the positive-ion ESI-MS of Arg and Pro-Arg, respectively. Peptide-triggered color and absorbance change of AuNPs suspension in the absence and presence of DPP-IV was first investigated by naked eyes and UV-Vis spectrophotometer. As shown in Figure 1A, the red AuNPs solution (tube a) showed an absorption peak at $520 \mathrm{~nm}$ (curve a). Upon addition of the tripeptide Arg-Pro-Arg, the color of AuNPs suspension changed from red to blue (tube b). Meanwhile, the original absorbance of AuNPs suspension at $520 \mathrm{~nm}$ decreased while a new absorbance peak at $\sim 630 \mathrm{~nm}$ appeared (curve b). Moreover, we found that the zeta potential of AuNPs changed from -43.9 to -22.1 with the addition of Arg-Pro-Arg, and their size increased from $13 \mathrm{nM}$ to $615 \mathrm{~nm}$ by dynamic light scattering (DLS) (Figure 1B). The aggregation of AuNPs can be attributed to the electrostatic interaction between the negatively charged citrate-capped AuNPs and the positively charged arginine residues in the two terminals of the tripeptide [21]. However, once the tripeptide was pre-incubated with DPP-IV for a given time, the AuNPs suspension kept at red (tube c) and showed one absorption peak at $520 \mathrm{~nm}$ (curve c), indicating that the cleavage products of arginine and dipeptide Pro-Arg could not crosslink AuNPs and cause their aggregation. In fact, we also found that the mixture of arginine and dipeptide Pro-Arg at the concentration of $5 \mu \mathrm{M}$ indeed did not induce the aggregation and color change of AuNPs suspension, further confirming the rationality of our design strategy. Furthermore, the tripeptide-triggered aggregation of AuNPs was verified by the TEM observation (Figure 1C). AuNPs aggregated significantly in the presence of peptide only (panel a), but they were monodisperse when the tripeptide was clipped by DPP-IV (panel b).

To optimize the experimental conditions for DPP-IV assay, we first investigated the dependence of AuNPs aggregation on the tripeptide concentration. The $A_{630} / A_{520}$ ratio was used to evaluate the analytical performances, wherein $\mathrm{A}_{630}$ and $\mathrm{A}_{520}$ represented the absorption intensity of the AgNPs suspension at $630 \mathrm{~nm}$ and $520 \mathrm{~nm}$, respectively. It can be observed that the $A_{630} / A_{520}$ increased linearly in the tripeptide concentration ranging from 0 to $1.5 \mu \mathrm{M}$ (Figure 2A). Thus, the optimized concentration ratio of peptide to AuNPs was estimated to be 417:1. Cleavage time has a profound influence on the cleavage reaction. We also studied the influence of cleavage time on the absorbance change of AuNPs. The $A_{630} / A_{520}$ decreased with the increase of cleavage time (Figure $2 \mathrm{~B}$ ) and began to level off beyond 
$60 \mathrm{~min}$. The result indicated that a sufficient reaction time is beneficial for a complete cleavage reaction. Thus, in the following detection assay, the peptide was allowed to be clipped by DPP-IV for $60 \mathrm{~min}$.
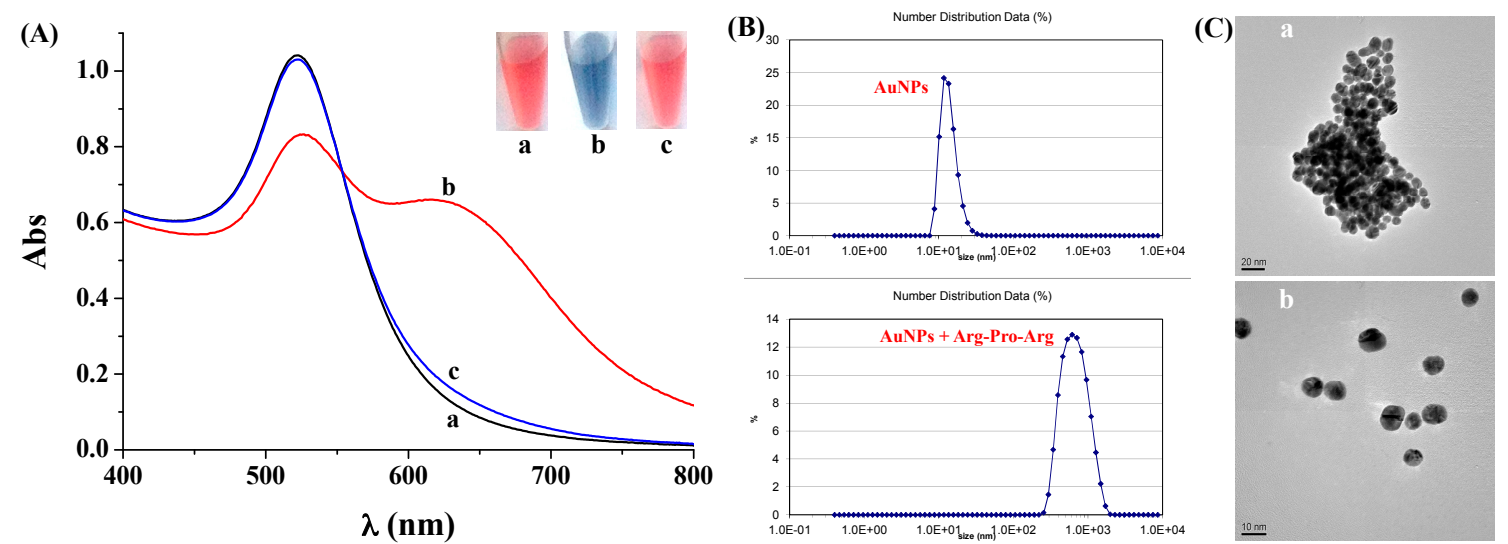

Figure 1. (A) UV-vis absorption spectra and photographic images of AuNPs in various systems (curve/tube a, AuNPs; curve/tube b, AuNPs + tripeptide; curve/tube c, AuNPs + tripeptide/DPP-IV). The final concentrations of AuNPs, tripeptide and DPP-IV were $3.6 \mathrm{nM}, 5 \mu \mathrm{M}$ and $250 \mathrm{mU} / \mathrm{mL}$, respectively; (B) dynamic light scattering (DLS) of AuNPs in the absence and presence of tripeptide Arg-Pro-Arg; (C) TEM images of AuNPs in the presence of tripeptide (panel a) and tripeptide/DPP-IV (panel b).
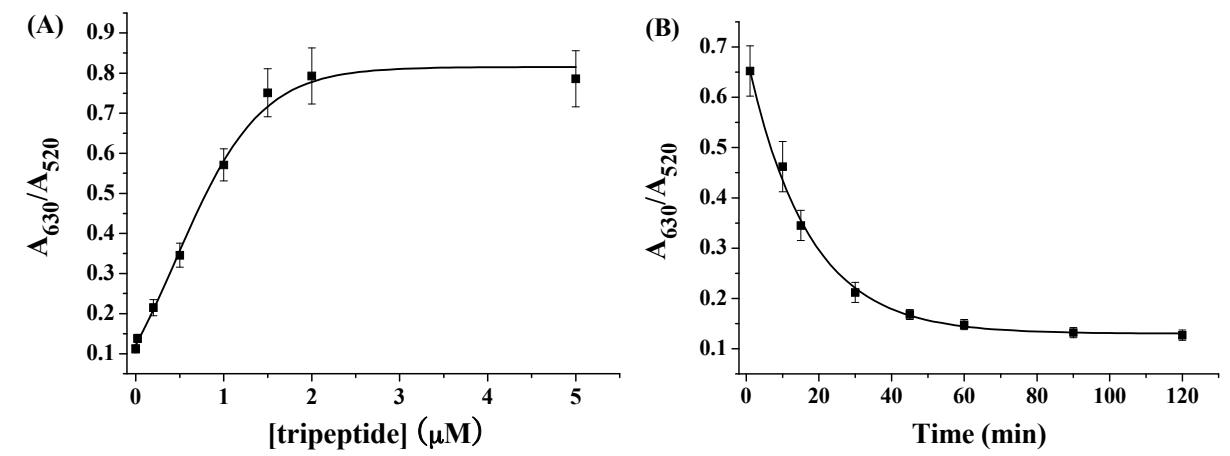

Figure 2. Dependence of the $\mathrm{A}_{630} / \mathrm{A}_{520}$ on the tripeptide concentration (A) and DPP-IV cleavage time; (B) The final concentration of AuNPs was $3.6 \mathrm{nM}$. The final concentrations of tripeptide and DPP-IV in pane B were $2 \mu \mathrm{M}$ and $250 \mathrm{mU} / \mathrm{mL}$, respectively.

\subsection{Effect of DPP-IV Concentration and Activity on the Colorimetric Assay}

Under the optimal conditionals, the sensitivity and detection limit of the colorimetric assay were demonstrated. Figure 3 shows the color and absorption change of AuNPs with the addition of the mixture of peptide and different amounts of DPP-IV. The colorimetric assay allowed for the determination of DPP-IV concentration as low as $5 \mathrm{mU} / \mathrm{mL}$ for rapid and reliable visualization by comparison with the blank sample (Figure 3A). Furthermore, the concomitant absorbance change was monitored by UV/Vis spectroscopy. As shown in Figure 3B, increase of DPP-IV concentration induced the decrease in the absorbance at $630 \mathrm{~nm}$. The dependence of the $\mathrm{A}_{630} / \mathrm{A}_{520}$ on the DPP-IV concentration was shown in Figure $3 C$. It can be observed that $A_{630} / A_{520}$ decreased linearly with DPP-IV concentration in the range of $0.1-50 \mathrm{mU} / \mathrm{mL}$. The linear regression equation can be expressed as $\mathrm{A}_{630} / \mathrm{A}_{520}=0.725$ [DPP-IV] $(\mathrm{mU} / \mathrm{mL})-0.008, \mathrm{R}=0.993$. The detection limit was determined to be $70 \mu \mathrm{U} / \mathrm{mL}$ based on the slope of the dose-response curve and the standard deviation of blank responses $(n=11)$. It has been suggested that DPP-IV inhibitor can increase the half-life of incretins, decrease the concentration of plasma glucose, and improve impaired glucose tolerance [2]. To demonstrate that 
the colorimetric method could be used for screening of DPP-IV inhibitor, diprotin A (a well-known DPP-IV inhibitor) was tested. As shown in Figure 3D, the inhibitor ratio increased with the increasing concentration of inhibitor in the range of 100 1000 $\mu \mathrm{M}$. The maximum inhibition of diprotin A was found to be $92.1 \%$. The half-maximal inhibitory concentration $\left(\mathrm{IC}_{50}\right)$ for $50 \mathrm{mU} / \mathrm{mL} \mathrm{DPP-IV} \mathrm{was}$ determined to be approximately $577 \mu \mathrm{M}$.
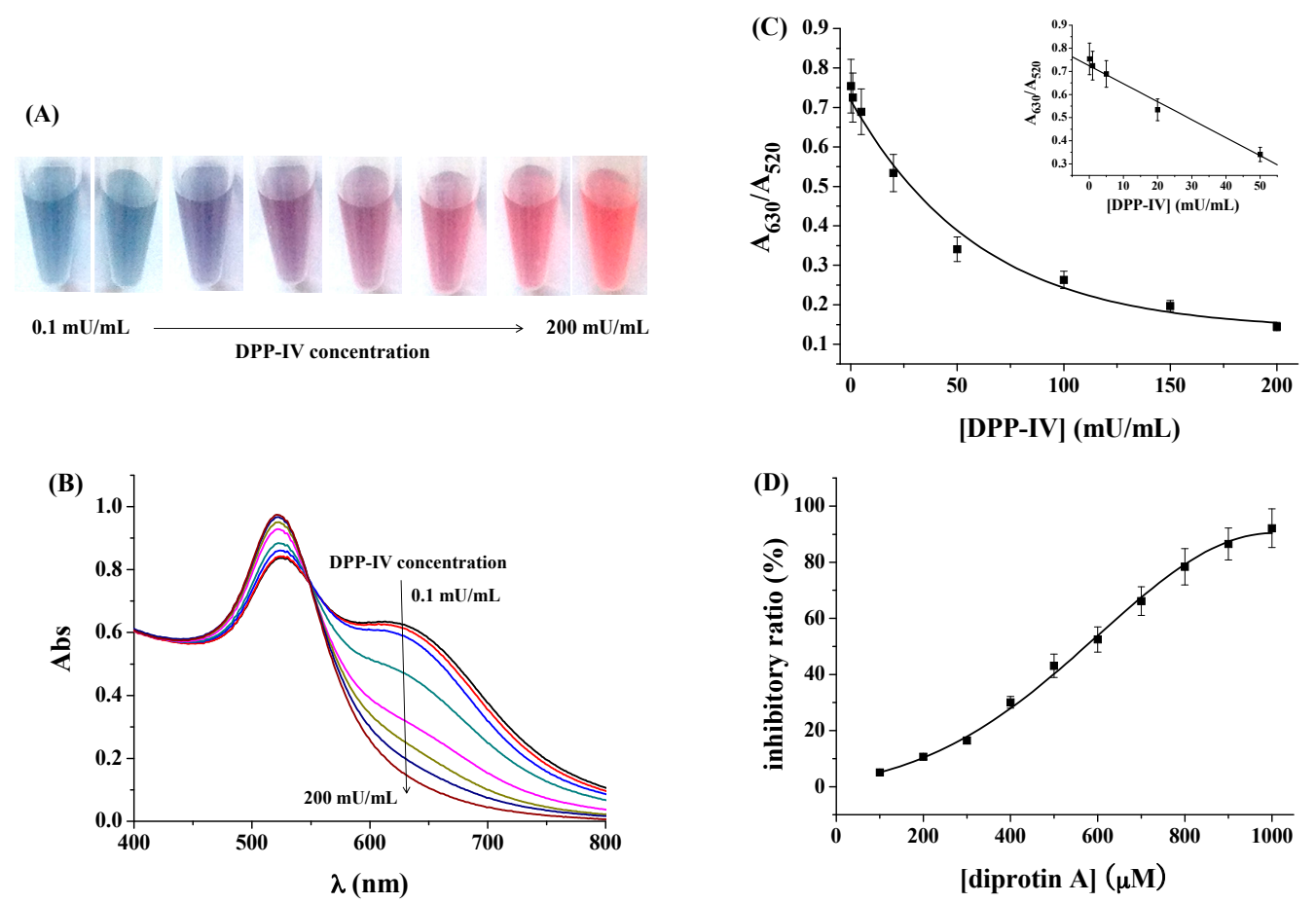

Figure 3. Photographic images (A) and UV-vis absorption spectra; (B) of AuNPs in the presence of peptide and various concentrations of $\operatorname{DPP}-\operatorname{IV}(0.1,1,5,20,50,100,150$ and $200 \mathrm{mU} / \mathrm{mL})$; (C) Dependence of the $\mathrm{A}_{630} / \mathrm{A}_{520}$ on the DPP-IV concentration. The final concentrations of AuNPs and peptide were $3.6 \mathrm{nM}$ and $2 \mu \mathrm{M}$, respectively; (D) Inhibitory ratio of different concentrations of diprotin A $(100,200,300,400,500,600,700,800,900$ and $1000 \mu \mathrm{M})$ on the DPP-IV (50 mU/mL) activity.

\subsection{Electrochemical Assay of DPP-IV}

The principle of the electrochemical strategy for assay of DPP-IV activity is presented in Scheme 2. The SAM of peptide/6-mercapto-1-hexanol (MCH) formed on the gold electrode surface behaves as a barrier for $\left[\mathrm{Fe}(\mathrm{CN})_{6}\right]^{3-} /\left[\mathrm{Fe}(\mathrm{CN})_{6}\right]^{4-}$. However, the sensing electrode can capture AuNPs and free tripeptide in the solution through the peptide-AuNPs-tripeptide interaction. Then, surface-tethered peptide-AgNPs-tripeptide recruited more AuNPs as well as tripeptide, resulting in the formation of a network of AuNPs-tripeptide on the electrode surface. The unique electrical properties of AuNPs may lead to a significant fall of charge transfer resistance [41-43]. Once the peptide ether on the electrode surface or in the solution was clipped by DPP-IV, it would lose the ability to trigger the assembly of AuNPs on the electrode surface. Thus, the liquid-phase colorimetric assay was converted into an electrochemical assay.

Electrochemical impedance spectroscopy (EIS) was used herein to monitor the change of surface properties. The impedance spectra were fitted with a Randles equivalent circuit, including the electrolyte resistance between working and reference electrodes $\left(R_{S}\right)$, the Warburg impedance $\left(Z_{W}\right)$, a constant phase element representing the double layer capacitance for an unmodified electrode or the capacitance of the self-assembled monolayers for the modified electrodes $(Q)$ and the electron-transfer resistance $\left(R_{e t}\right)$ (see the inset in Figure $4 \mathrm{~A}$ ). The $R_{\text {et }}$ on the peptide/MCH-covered electrode (curve b) was significantly higher than that on the bare gold electrode (curve a). The result is understandable 
since the peptide/MCH SAM can repulse $\left[\mathrm{Fe}(\mathrm{CN})_{6}\right]^{3-} /\left[\mathrm{Fe}(\mathrm{CN})_{6}\right]^{4-}$ from the electrode surface [44]. However, after incubating the peptide/MCH-covered electrode with AuNPs/peptide (curve d), the $\mathrm{R}_{\mathrm{et}}$ decreased significantly. Note that there is no apparent resistance change when incubating the electrode with peptide only (data not shown) and a smaller decrease in $R_{\mathrm{et}}$ was observed when incubating the electrode with AuNPs alone (curve c). Thus, the significant decrease in the $R_{\mathrm{et}}$ of curve $\mathrm{d}$ was attributed the formation of a network of AuNPs. Furthermore, there is an increase in $R_{\mathrm{et}}$ when incubating the sensing electrode with DPP-IV (curve d), demonstrating that remove of one positively charged arginine residue from the electrode surface caused the change of surface properties. However, no significant decrease in $R_{\text {et }}$ was observed when incubating the DPP-IV-treated electrode with AuNPs/peptide (curve f), and the $R_{\text {et }}$ in this case was greatly higher than that of curve $d$. Thus, cleavage of the peptide by DPP-IV made the assembly of AuNPs on electrode surface impossible. This was further confirmed by the SEM observation. As shown in Figure 4B, a network of AuNPs was formed on the peptide/MCH-covered sensing electrode surface (panel a), but fewer AuNPs were absorbed on the DPP-IV-treated sensing electrode surface (panel b). These results were acceptable since the cleavage products showed no or poor binding to AuNPs and could not crosslink AuNPs, which could be demonstrated by the above colorimetric assay. These results confirmed that the liquid-phase colorimetric assay was developed into an electrochemical analysis.
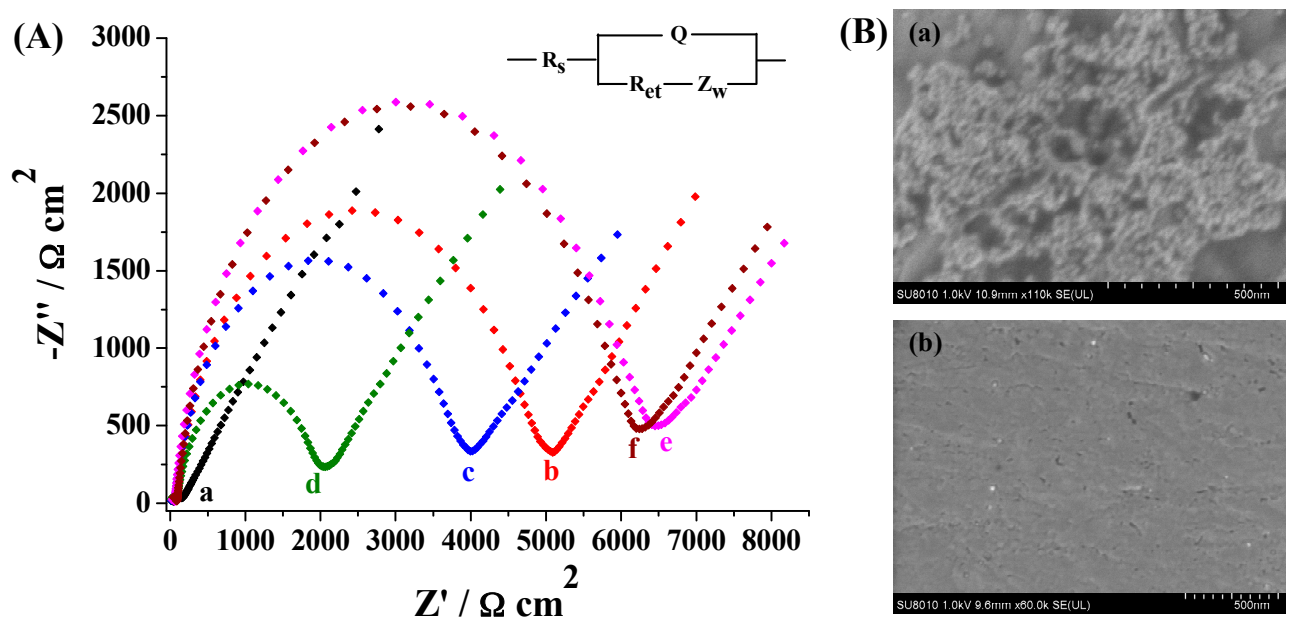

Figure 4. (A) Electrochemical impedance spectroscopy (EIS) of the bare electrode (curve a) and peptide/6-mercapto-1-hexanol (MCH)-modified electrode before (curve b) and after incubation with AuNPs (curve c) or AuNPs / peptide (curve d). Curve e corresponds to that after incubation with DPP-IV only. Curve f corresponds to that of incubation with AuNPs/peptide following the incubation with DPP-IV. The final concentrations of AuNPs, peptide and DPP-IV were $1.8 \mathrm{nM}, 0.4 \mu \mathrm{M}$ and $5 \mathrm{mU} / \mathrm{mL}$, respectively; (B) SEM images of peptide/MCH-modified electrode incubated with AuNPs/peptide before (panel a) and after treatment (curve b) by DPP-IV.

\subsection{Optimization of Experimental Conditions for Impedance Assay}

Higher concentration of tripeptide (Arg-Pro-Arg) can make the AuNPs aggregation more powerful. However, higher concentration of tripeptide in the solution would compete with the immobilized peptide substrate to bind AuNPs, thus deteriorating the assembly of AuNPs. To facilitate the electrochemical detection of DPP-IV, we first investigated the influence of the concentration ratio of peptide to AuNPs (tripeptide)/(AuNPs) on the $R_{\mathrm{et}}$ value. It was found that $R_{\mathrm{et}}$ was initially decreased with the increasing (tripeptide)/(AuNPs) ratio until the minimum value appeared at 167, followed by a sharp increase (Figure 5A). Also, the influence of the AuNPs/tripeptide concentration on the electrochemical impedance was investigated. As a result, $R_{\mathrm{et}}$ decreased with the increase of AuNPs/tripeptide concentration and began to level off beyond $0.9 \mathrm{nM}$ (AuNPs concentration) 
(Figure 5B). Therefore, in the following detection assay, the concentrations of the AuNPs and tripeptide were kept at $1.2 \mathrm{nM}$ and $0.2 \mu \mathrm{M}$, respectively.
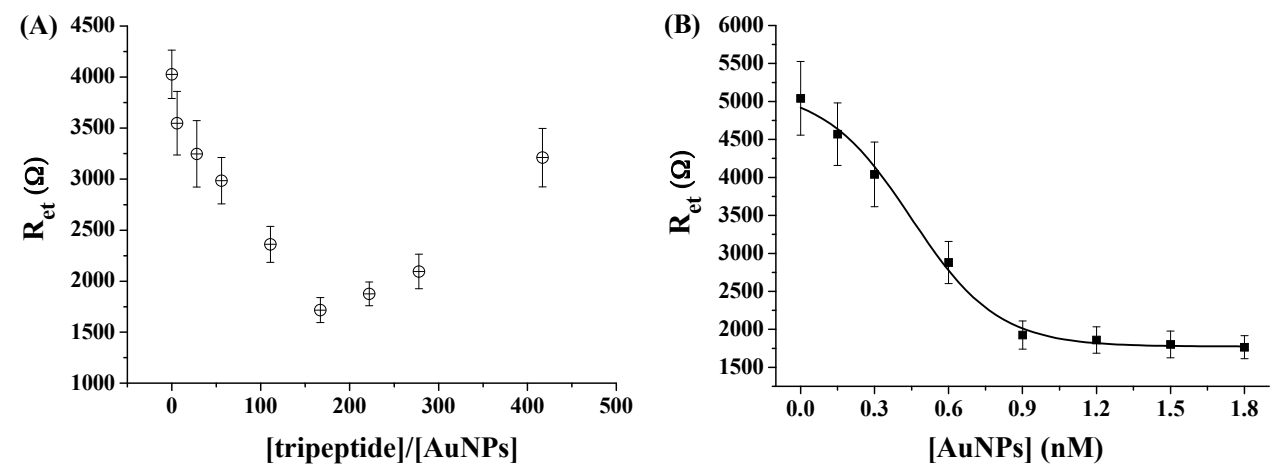

Figure 5. (A) Dependence of $R_{e t}$ on the concentration ratio of the tripeptide to AuNPs. The final concentration of AuNPs was $1.8 \mathrm{nM}$ and that of the peptide varied from 0 to $0.75 \mu \mathrm{M}(0,0.01,0.05,0.1$, $0.2,0.3,0.4,0.5$ and $0.75 \mu \mathrm{M})$; (B) Dependence of $R_{e t}$ on the AuNPs concentration. The concentration ratio of the tripeptide to AuNPs kept at 167.

\subsection{Sensitivity to DPP-IV}

Under the optimized experimental conditions, DPP-IV at various concentrations was analyzed. The quantitative assay was conducted by measuring the change of electron transfer resistance $\left(\Delta R_{\mathrm{et}}=\mathrm{R}_{\mathrm{et}}^{\prime}-\mathrm{R}_{\mathrm{et}}\right.$, where $\mathrm{R}_{\mathrm{et}}^{\prime}$ and $\mathrm{R}_{\mathrm{et}}$ represent the electron transfer resistance of the sensing electrode with and without treatment by DPP-IV, respectively, followed by incubation with AuNPs/peptide). As shown in Figure 6A, $\Delta \mathrm{R}_{\mathrm{et}}$ increased with increasing DPP-IV concentration (DPP-IV). It was proportional to (DPP-IV) in the range from 0.001 to $0.5 \mathrm{mU} / \mathrm{mL}$. The regression equation was $\Delta \mathrm{R}_{\mathrm{et}}=7738(\mathrm{DPP}-\mathrm{IV})(\mathrm{mU} / \mathrm{mL})+56, \mathrm{R}=0.977$. The detection limit of this electrochemical method was calculated to be $0.55 \mu \mathrm{U} / \mathrm{mL}$. The value was approximately 2 orders of magnitude lower than that obtained by the aforementioned AuNP-based colorimetric method $(70 \mu \mathrm{U} / \mathrm{mL})$, demonstrating that AuNP-based liquid-phase colorimetric assay has been converted into the electrochemical assay with improving sensitivity. The detection limit of our electrochemical method is comparable to that $(39 \mathrm{nU} / \mathrm{mL}$ ) achieved on the AuNPs-modified electrode by using a ferrocence-labeled peptide as the probe [12]. Furthermore, the electrochemical method was used to determine DPP-IV inhibitor. It was found that the $R_{\mathrm{et}}$ decreased with the increasing concentration of diprotin $\mathrm{A}$ in the range of $1-15 \mu \mathrm{M}$. The maximum inhibition was found to be $95.8 \%$ with the $\mathrm{IC}_{50}$ value of $\sim 5.6 \mu \mathrm{M}$ (Figure $6 \mathrm{~B}$ ).
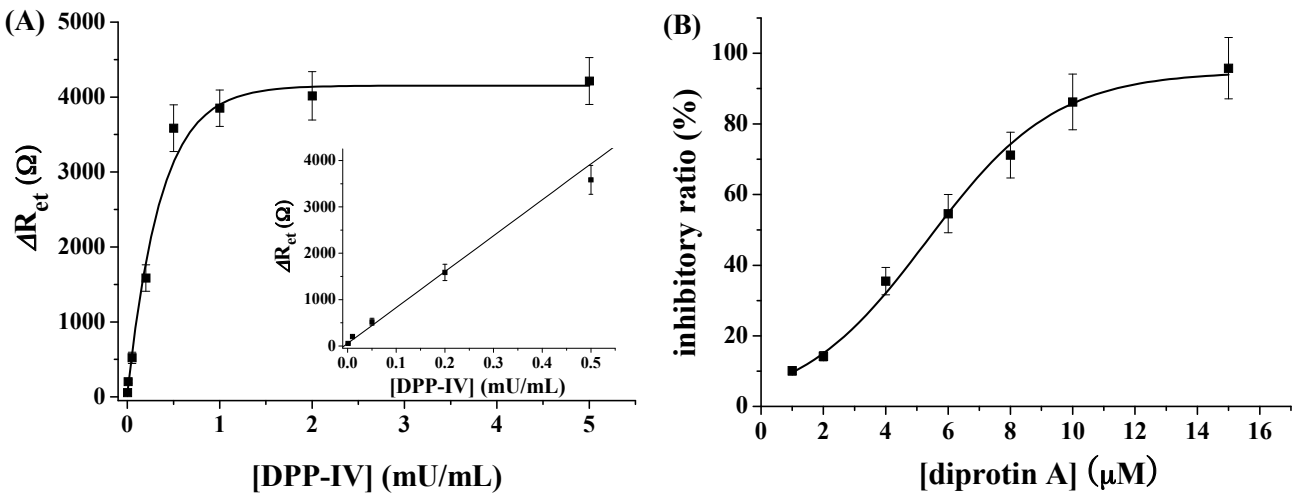

Figure 6. (A) Dependence of $\Delta \mathrm{R}_{\mathrm{et}}$ on DPP-IV concentration $(0,0.001,0.01,0.05,0.2,0.5,1,2$ and $5 \mathrm{mU} / \mathrm{mL})$; (B) Inhibitory ratio of different concentrations of diprotin $\mathrm{A}(1,2,4,6,8,10$ and $15 \mu \mathrm{M})$ on the DPP-IV $(0.5 \mathrm{mU} / \mathrm{mL})$ activity. 


\section{Materials and Methods}

\subsection{Reagents and Materials}

Peptides with the sequences of Pro-Arg, Arg-Pro-Arg and Arg-Pro-Arg-Pro-Pro-Pro-Pro-Cys ( $\geq 98 \%$ ) were synthesized and purified by Synpeptide Co., Ltd. (Shanghai, China). DPP-IV, diprotin A, tris(2-carboxyethyl)phosphine hydrochloride (TCEP), trisodium citrate, 6-mercapto-1-hexanol (MCH), $\mathrm{KH}_{2} \mathrm{PO}_{4}$ and $\mathrm{K}_{2} \mathrm{HPO}_{4}$ were purchased from Sigma-Aldrich (Shanghai, China). Other reagents were analytical-grade and used without additional treatment. The peptide stock solution at the concentration of $2 \mathrm{mM}$ was dissolved with deionized water and diluted with a phosphate-buffered saline solution (PBS buffer, 2 mM, pH 7.6) before use. The citrate-stabilized AuNPs with a size of 13 nm were prepared using a trisodium citrate reduction method [45]. The concentration of synthesized AuNPs was determined by Beer's law with an extinction coefficient of $2.7 \times 10^{8} \mathrm{M}^{-1} \mathrm{~cm}^{-1}$ [18]. Unless otherwise noted, the reactions were conducted at room temperature.

\subsection{Instruments}

The UV/Vis spectra were collected on a Cary 60 spectrophotometer using a $1 \mathrm{~cm}$ quartz spectrophotometer cell. The photograph was taken by a digital camera. The transmission electron microscope (TEM) images were taken by an FEI Tecnai G2 T20 TEM (Hillsboro, OR, USA). Scanning electron microscope (SEM) images were taken on a Hitachi SU8010 SEM (Tokyo, Japan). Dynamic light scattering (DLS) and zeta potentials $(\zeta)$ were measured on a Malvern Zetasizer Nano-ZS (Malvern, Worcetershire, UK). The enzymatic products were characterized by mass spectroscopy (LCT Premier XE, Waters, Milford, MA, USA). The electrochemical experiments were carried out on a CHI 660E (CH Instruments, Inc., Shanghai, China) electrochemical workstation. The auxiliary electrode is a platinum wire. The reference electrode is $\mathrm{Ag} / \mathrm{AgCl}$.

\subsection{Colorimetric Assay of DPP-IV Activity}

To investigate the effect of peptide Arg-Pro-Arg on the AuNPs aggregation, $250 \mu \mathrm{L}$ of AuNPs suspension was added to $250 \mu \mathrm{L}$ of a known concentration of peptide solution. After incubation for $5 \mathrm{~min}$, color change was observed with the naked eyes and the photograph was taken by a digital camera. UV/Vis absorption spectra were collected with the spectrophotometer. To determine the activity of DPP-IV, $200 \mu \mathrm{L}$ of peptide solution was incubated with $50 \mu \mathrm{L}$ of DPP-IV solution in a test tube at room temperature. After reaction for a given time, the solution was mixed with $250 \mu \mathrm{L}$ of AuNPs for $5 \mathrm{~min}$. The color and absorption change of the mixture were then measured by the digital camera and the UV/Vis spectrophotometer, respectively.

To evaluate the inhibition ability of the potential inhibitor, DPP-IV was first mixed with the tested inhibitor for $30 \mathrm{~min}$. Then, peptide was added into the mixture to react for $1 \mathrm{~h}$. The other detection procedures are the same as those for the detection of DPP-IV. The inhibitory ratio $(\%)$ of the potential inhibitors on enzymatic activity was expressed as follows: inhibitory ratio $(\%)=\left(R_{3}-R_{2}\right) /\left(R_{1}-R_{2}\right) \times 100 \%$, where $R_{1}$ is the $A_{630} / A_{520}$ ratio of AuNPs/peptide in the absence of DPP-IV, $R_{2}$ is the $A_{630} / A_{520}$ ratio of AuNPs/peptide in the presence of DPP-IV, $R_{3}$ is the $A_{630} / A_{520}$ ratio of AuNPs/peptide in the presence of DPP-IV and inhibitor.

\subsection{Electrochemical Assay of DPP-IV Activity}

The cleaned polycrystalline gold disk electrode was placed in a $100 \mu \mathrm{L}$ PBS solution comprising of $10 \mu \mathrm{M}$ cysteine-containing peptide (Arg-Pro-Arg-Pro-Pro-Pro-Pro-Cys) and $50 \mathrm{mM}$ TCEP for 12 h. The peptide was assembled onto the electrode surface through the Au-S interaction. Insertion of the four proline residues between the substrate and the cysteine residue could help position the peptide away from the electrode surface to achieve a higher enzyme cleavage efficiency [46,47]. After the formation of the peptide self-assembled monolayers (SAMs) on electrode surface, the electrode was soaked in a solution of $1 \mathrm{mM} \mathrm{MCH}$ for $30 \mathrm{~min}$. Then, the electrode was rinsed thoroughly with ethanol 
and water to remove non-specifically adsorbed substance. Modification of electrode with MCH can block the unreacted gold surface and displace non-specifically adsorbed peptide. For the assay of DPP-IV activity, the peptide/MCH-covered electrode was first pre-incubated with $50 \mu \mathrm{L}$ of DPP-IV solution in a homemade plastic cell for $30 \mathrm{~min}$. Then, $50 \mu \mathrm{L}$ of peptide (Arg-Pro-Arg) solution was added into the tube for 60 min-incubation, followed by addition of $100 \mu \mathrm{L}$ of AuNPs suspension. After incubation for $10 \mathrm{~min}$ again, the electrode was rinsed thoroughly with water and then placed in the electrolyte for impedance measurement in the frequency range of $0.01-500 \mathrm{kHz}$. The electrolyte was comprised of $10 \mathrm{mM}\left[\mathrm{Fe}(\mathrm{CN})_{6}\right]^{3-} /\left[\mathrm{Fe}(\mathrm{CN})_{6}\right]^{4-}(1: 1)$ and $0.5 \mathrm{M} \mathrm{KCl}$ and the potential was set at $0.245 \mathrm{~V}$.

To evaluate the inhibition ability of the potential inhibitors, DPP-IV was first mixed with the tested inhibitor for $10 \mathrm{~min}$. The other detection procedures were the same as those for the detection of DPP-IV. The inhibitory ratio (\%) of the potential inhibitors on enzymatic activity was expressed as follows: inhibitory ratio $(\%)=\left(\mathrm{R}_{\mathrm{et}}^{3}-\mathrm{R}_{\mathrm{et}}{ }^{2}\right) /\left(\mathrm{R}_{\mathrm{et}}{ }^{1}-\mathrm{R}_{\mathrm{et}}{ }^{2}\right) \times 100 \%$, where $\mathrm{R}_{\mathrm{et}}{ }^{1}$ is the electron-transfer resistance in the case without DPP-IV, $\mathrm{R}_{\mathrm{et}}{ }^{2}$ is the electron-transfer resistance in the case with DPP-IV, $\mathrm{R}_{\mathrm{et}}{ }^{3}$ is the electron-transfer resistance in the case with DPP-IV and inhibitor.

\section{Conclusions}

In summary, we presented the colorimetric and electrochemical methods for DPP-IV activity assay and inhibitor screening based on the unique size-dependent optical property and the good electrical ability of AuNPs. DPP-IV could be detected with a detection limit of $70 \mu \mathrm{U} / \mathrm{mL}$ by UV/vis spectra or $0.55 \mu \mathrm{U} / \mathrm{mL}$ by the electrochemical method. The proposed methods could also be used for determining DPP-IV inhibitor. Compared with the traditional methods, the colorimetric method requires very simple detection procedure and minimum instrumental investment. Furthermore, the AuNP-based liquid-phase colorimetric method could be developed into an enhanced surface tethered electrochemical method. Such conversion improved the sensitivity and maintained the simple detection principle and easy manipulation procedure of the colorimetric method. We believe that this work should be valuable for detection of DPP-IV activity, screening of novel DPP-IV inhibitors and design of new peptidases biosensors.

Acknowledgments: Partial support of this work by the National Natural Science Foundation of China (21305004), the Joint Fund for Fostering Talents of National Natural Science Foundation of China and Henan Province (U1304205) and the Science \& Technology Foundation of Henan Province (17A150001) is gratefully acknowledged.

Author Contributions: Ning Xia conceived and designed the experiments and wrote the paper; Xin Wang performed the colorimetric experiments; Xiaojin Wang and Binbin Zhou performed the electrochemical experiments and analyzed the data.

Conflicts of Interest: The authors declare no conflict of interest. The founding sponsors had no role in the design of the study; in the collection, analyses, or interpretation of data; in the writing of the manuscript, and in the decision to publish the results.

\section{References}

1. Wang, F.; Yu, G.; Zhang, Y.; Zhang, B.; Fan, J. Dipeptidyl peptidase IV inhibitory peptides derived from oat (avena sativa L.), buckwheat (fagopyrum esculentum), and highland barley (hordeum vulgare trifurcatum (L.) trofim) proteins. J. Agric. Food Chem. 2015, 63, 9543-9549. [CrossRef] [PubMed]

2. Zhang, Y.; Chen, R.; Ma, H.; Chen, S. Isolation and identification of dipeptidyl peptidase IV-inhibitory peptides from trypsin/chymotrypsin-rreated goat milk casein hydrolysates by 2D-TLC and LC-MS/MS. J. Agric. Food Chem. 2015, 63, 8819-8828. [CrossRef] [PubMed]

3. De Mello, H.A.; Prá, M.; Cardoso, C.L.; De Bona, S.R.; Rezin, T.G. Incretin-based therapies for obesity treatment. Metab. Clin. Exp. 2015, 64, 967-981. [CrossRef] [PubMed]

4. Sebokova, E.; Christ, A.D.; Boehringer, M.; Mizrahi, J. Dipeptidyl peptidase IV inhibitors: The next generation of new promising therapies for the management of type 2 diabetes. Curr. Top. Med. Chem. 2007, 7, 547-555. [CrossRef] [PubMed] 
5. Tanwar, O.; Tanwar, L.; Shaquiquzzaman, M.; Alam, M.M.; Akhter, M. Structure based virtual screening of MDPI database: Discovery of structurally diverse and novel DPP-IV inhibitors. Bioorg. Med. Chem. Lett. 2014, 24, 3447-3451. [CrossRef] [PubMed]

6. Lin, Y.S.; Han, C.H.; Lin, S.Y.; Hou, W.C. Synthesized peptides from yam dioscorin hydrolysis in silico exhibit dipeptidyl peptidase-IV inhibitory activities and oral glucose tolerance improvements in normal mice. J. Agric. Food Chem. 2016, 64, 6451. [CrossRef] [PubMed]

7. Li, S.; Xu, H.; Cui, S.; Wu, F.; Zhang, Y.; Su, M.; Gong, Y.; Qiu, S.; Jiao, Q.; Qin, C.; et al. Discovery and rational design of natural-product-derived 2-phenyl-3,4-dihydro-2H-benzo[f]chromen-3-amine analogs as novel and potent dipeptidyl peptidase 4 (DPP-4) inhibitors for the treatment of type 2 diabetes. J. Med. Chem. 2016, 59, 6772-6790. [CrossRef] [PubMed]

8. Wu, W.L.; Hao, J.; Domalski, M.; Burnett, D.A.; Pissarnitski, D.; Zhao, Z.; Stamford, A.; Scapin, G.; Gao, Y.D.; Soriano, A.; et al. Discovery of novel tricyclic heterocycles as potent and selective DPP-4 inhibitors for the treatment of type 2 diabetes. ACS Med. Chem. Lett. 2016, 7, 498-501. [CrossRef] [PubMed]

9. Lai, K.S.; Ho, N.H.; Cheng, J.D.; Tung, C.H. Selective fluorescence probes for dipeptidyl peptidase activitys fibroblast activation protein and dipeptidyl peptidase IV. Bioconj. Chem. 2007, 18, 1246-1250. [CrossRef] [PubMed]

10. Kim, Y.B.; Kopcho, L.M.; Kirby, M.S.; Hamann, L.G.; Weigelt, C.A.; Metzler, W.J.; Marcinkeviciene, J. Mechanism of Gly-Pro-pNA cleavage catalyzed by dipeptidyl peptidase-IV and its inhibition by saxagliptin (BMS-477118). Arch. Biochem. Biophys. 2006, 445, 9-18. [CrossRef] [PubMed]

11. Tinoco, A.D.; Tagore, D.M.; Saghatelian, A. Expanding the dipeptidyl peptidase 4-regulated peptidome via an optimized peptidomics platform. J. Am. Chem. Soc. 2010, 132, 3819-3830. [CrossRef] [PubMed]

12. Zhang, J.; Liu, Y.; Lv, J.; Cao, Y.; Li, G. Dipeptidyl peptidase-IV activity assay and inhibitor screening using a gold nanoparticle-modified gold electrode with an immobilized enzyme substrate. Microchim. Acta 2015, 182, 281-288. [CrossRef]

13. Gao, H.J.; Pan, D.D.; Gan, N.; Cao, J.X.; Sun, Y.Y.; Wu, Z.; Zeng, X.Q. An aptamer-based colorimetric assay for chloramphenicol using a polymeric HRP-antibody conjugate for signal amplification. Microchim. Acta 2015, 182, 2551-2559. [CrossRef]

14. Ronkainen, N.J.; Okon, S.L. Nanomaterial-based electrochemical immunosensors for clinically significant biomarkers. Materials 2014, 7, 4669-4709. [CrossRef]

15. Zhang, Y.; Chu, W.; Foroushani, A.D.; Wang, H.; Li, D.; Liu, J.; Barrow, C.J.; Wang, X.; Yang, W. New gold nanostructures for sensor applications: A review. Materials 2014, 7, 5169-5201. [CrossRef]

16. Xia, N.; Wang, X.; Yu, J.; Wu, Y.; Cheng, S.; Xing, Y.; Liu, L. Design of electrochemical biosensors with peptide probes as thereceptors of targets and the inducers of gold nanoparticles assemblyon electrode surface. Sens. Actuators B Chem. 2017, 239, 834-840. [CrossRef]

17. Katz, E.; Willner, I. Integrated nanoparticle-biomolecule hybrid systems: Synthesis, properties, and applications. Angew. Chem. Int. Ed. 2004, 43, 6042-6108. [CrossRef] [PubMed]

18. Liu, L.; Xia, N.; Liu, H.P.; Kang, X.J.; Liu, X.S.; Xue, C.; He, X.L. Highly sensitive and label-free electrochemical detection of microRNAs based on triple signal amplification of multifunctional gold nanoparticles, enzymes and redox-cycling reaction. Biosens. Bioelectron. 2014, 53, 399-405. [CrossRef] [PubMed]

19. Liu, L.; Zhao, F.; Ma, F.; Zhang, L.; Yang, S.; Xia, N. Electrochemical detection of $\beta$-amyloid peptides on electrode covered with $\mathrm{N}$-terminus-specific antibody based on electrocatalytic $\mathrm{O}_{2}$ reduction by $\mathrm{A} \beta(1-16)$ heme-modified gold nanoparticles. Biosens. Bioelectron. 2013, 49, 231-235. [CrossRef] [PubMed]

20. Xia, N.; Zhang, L.; Wang, G.; Feng, Q.; Liu, L. Label-free and sensitive strategy for microRNAs detection based on the formation of boronate ester bonds and the dual-amplification of gold nanoparticles. Biosens. Bioelectron. 2013, 2013, 461-466. [CrossRef] [PubMed]

21. Choi, Y.; Ho, N.H.; Tung, C.H. Sensing phosphatase activity by using gold nanoparticles. Angew. Chem. Int. Ed. 2007, 46, 707-709. [CrossRef] [PubMed]

22. Wang, Z.; Lévy, R.; Fernig, D.G.; Brust, M. Kinase-catalyzed modification of gold nanoparticles: A new approach to colorimetric kinase activity screening. J. Am. Chem. Soc. 2006, 128, 2214-2215. [CrossRef] [PubMed]

23. Xu, X.; Han, M.S.; Mirkin, C.A. A gold-nanoparticle-based real-time colorimetric screening method for endonuclease activity and inhibition. Angew. Chem. Int. Ed. 2007, 46, 3468-3470. [CrossRef] [PubMed] 
24. Guarise, C.; Pasquato, L.; De Filippis, V.; Scrimin, P. Gold nanoparticles-based protease assay. Proc. Natl. Acad. Sci. USA 2006, 103, 3978-3982. [CrossRef] [PubMed]

25. Ding, X.; Ge, D.; Yang, K.L. Colorimetric protease assay by using gold nanoparticles and oligopeptides. Sens. Actuators B Chem. 2014, 201, 234-239. [CrossRef]

26. Kim, C.J.; Lee, D.I.; Kim, C.; Lee, K.; Lee, C.H.; Ahn, I.S. Gold nanoparticles-based colorimetric assay for cathepsin B activity and the efficiency of its inhibitors. Anal. Chem. 2014, 86, 3825-3833. [CrossRef] [PubMed]

27. Elghanian, R.; Storhoff, J.J.; Mucic, R.C.; Letsinger, R.L.; Mirkin, C.A. Selective colorimetric detection of polynucleotides based on the distance-dependent optical properties of gold nanoparticles. Science 1997, 277, 1078-1081. [CrossRef] [PubMed]

28. He, L.; Musick, M.D.; Nicewarner, S.R.; Salinas, F.G.; Benkovic, S.J.; Natan, M.J.; Keating, C.D. Colloidal Au-enhanced surface plasmon resonance for ultrasensitive detection of DNA hybridization. J. Am. Chem. Soc. 2000, 122, 9071-9077. [CrossRef]

29. Li, H.X.; Rothberg, L. Colorimetric detection of DNA sequences based on electrostatic interactions with unmodified gold nanoparticles. Proc. Natl. Acad. Sci. USA 2004, 101, 14036-14039. [CrossRef] [PubMed]

30. Nam, J.-M.; Thaxton, C.S.; Mirkin, C.A. Nanoparticle-based bio-bar codes for the ultrasensitive detection of proteins. Science 2003, 301, 1884-1886. [CrossRef] [PubMed]

31. Niemeyer, C.M. Nanoparticles, proteins, and nucleic acids: Biotechnology meets materials science. Angew. Chem. Int. Ed. 2001, 40, 4128-4158. [CrossRef]

32. Lee, J.S.; Han, M.S.; Mirkin, C.A. Colorimetric detection of mercuric ion $\left(\mathrm{Hg}^{2+}\right)$ in aqueous media using DNA-functionalized gold nanoparticles. Angew. Chem. Int. Ed. 2007, 46, 4093-4096. [CrossRef] [PubMed]

33. Liu, J.; Lu, Y. Stimuli-responsive disassembly of nanoparticle aggregates for light-up colorimetric sensing. J. Am. Chem. Soc. 2005, 127, 12677-12683. [CrossRef] [PubMed]

34. Zhou, Y.; Wang, S.; Zhang, K.; Jiang, X. Visual detection of copper(II) by azide- and alkyne-functionalized gold nanoparticles using click chemistry. Angew. Chem. Int. Ed. 2008, 47, 7454-7456. [CrossRef] [PubMed]

35. Ai, K.; Liu, Y.; Lu, L. Hydrogen-bonding recognition-induced color change of gold nanoparticles for visual detection of melamine in raw milk and infant formula. J. Am. Chem. Soc. 2009, 131, 9496-9497. [CrossRef] [PubMed]

36. Jiang, Y.; Zhao, H.; Zhu, N.; Lin, Y.; Yu, P.; Mao, L. A simple assay for direct colorimetric visualization of trinitrotoluene at picomolar levels using gold nanoparticles. Angew. Chem. Int. Ed. 2008, 47, 8601-8604. [CrossRef] [PubMed]

37. Kong, B.; Zhu, A.; Luo, Y.; Tian, Y.; Yu, Y.; Shi, G. Sensitive and selective colorimetric visualization of cerebral dopamine based on double molecular recognition. Angew. Chem. Int. Ed. 2011, 50, 1837-1840. [CrossRef] [PubMed]

38. Zhu, Z.; Wu, C.; Liu, H.; Zou, Y.; Zhang, X.; Kang, H.; Yang, C.J.; Tan, W. Aptamer-crosslinked hydrogel as a colorimetric platform for visual detection. Angew. Chem. Int. Ed. 2010, 49, 1052-1056. [CrossRef] [PubMed]

39. Liu, L.; Li, S.; Liu, L.; Deng, D.; Xia, N. Simple, sensitive and selective detection of dopamine using dithiobis (succinimidylpropionate) -modified gold nanoparticles as colorimetric probes. Analyst 2012, 137, 3794-3799. [CrossRef] [PubMed]

40. Wei, T.; Dong, T.; Wang, Z.; Bao, J.; Tu, W.; Dai, Z. Aggregation of individual sensing units for signal accumulation: Conversion of liquid-phase colorimetric assay into enhanced surface-tethered electrochemical analysis. J. Am. Chem. Soc. 2015, 137, 8880-8883. [CrossRef] [PubMed]

41. Miao, P.; Wang, B.; Han, K.; Tang, Y. Electrochemical impedance spectroscopy study of proteolysis using unmodified gold nanoparticles. Electrochem. Commun. 2014, 47, 21-24. [CrossRef]

42. Yang, Y.; Li, C.; Yin, L.; Liu, M.; Wang, Z.; Shu, Y.; Li, G. Enhanced charge Transfer by gold nanoparticle at DNA modified electrode and its application to label-free DNA detection. ACS Appl. Mater. Interfaces 2014, 6, 7579-7584. [CrossRef] [PubMed]

43. Zhao, J.; Zhu, X.; Li, T.; Li, G. Self-assembled multilayer of gold nanoparticles for amplified electrochemical detection of cytochrome c. Analyst 2008, 133, 1242-1245. [CrossRef] [PubMed]

44. Liu, L.; Deng, D.; Xing, Y.; Li, S.; Yuan, B.; Chen, J.; Xia, N. Activity analysis of the carbodiimide-mediated amine coupling reaction on self-assembled monolayers by cyclic voltammetry. Electrochim. Acta 2013, 89, 616-622. [CrossRef] 
45. Xia, N.; Deng, D.; Zhang, L.; Yuan, B.; Jing, M.; Du, J.; Liu, L. Sandwich-type electrochemical biosensor for glycoproteins detection based on dual-amplification of boronic acid-gold nanoparticles and dopamine-gold nanoparticles. Biosens. Bioelectron. 2013, 43, 155-159. [CrossRef] [PubMed]

46. Nowinski, A.K.; Sun, F.; White, A.D.; Keefe, A.J.; Jiang, S. Sequence, structure, and function of peptide self-assembled monolayers. J. Am. Chem. Soc. 2012, 134, 6000-6005. [CrossRef] [PubMed]

47. Xia, N.; Zhang, Y.; Guan, P.; Hao, Y.; Liu, L. A simple and label-free electrochemical method for detection of beta-site amyloid precursor protein cleaving enzyme and screening of its inhibitor. Sens. Actuators B Chem. 2015, 213, 111-115. [CrossRef]

(C) 2016 by the authors; licensee MDPI, Basel, Switzerland. This article is an open access article distributed under the terms and conditions of the Creative Commons Attribution (CC-BY) license (http://creativecommons.org/licenses/by/4.0/). 